Grace Naomi B. Galvan. MD

Ma. Delhia A. De Leon MD

Romulus A. Instrella, MD

Nixon S. See, MD

Department of Otorhinolaryngology Head \& Neck Surgery Armed Forces of the Philippines Medical Center
Correspondence: Grace Naomi B. Galvan, MD Armed Forces of the Philippines Medical Center V. Luna Road, Diliman, Quezon City 0840 Philippines

Phone number: (632) 4262701 local 6972

E-mail: gracenaomigalvanmd@yahoo.com

Reprints will not be available from the author.

No funding support was received for this study. The authors signed disclosures that they have no proprietary or financial interest with an organization that may have a direct interest in the subject matter of this manuscript, or in any product used or cited in this study

Presented at the 10th Annual North East Manila ENT Consortium Interesting Case Contest, Valdes Hall, Veteran's Memorial Medical Center, March 27, 2008

\title{
Pleomorphic Adenoma Arising from Heterotropic Salivary Gland Tumor in a Supraclavicular Lymph Node
} \begin{abstract}
tissue in a supraclavicular lymph node.
\section{Methods:}

Design: Case report

Setting: Tertiary government hospital

Patient: One
\end{abstract}

ABSTRACT

Objective: To present a case of pleomorphic adenoma arising from heterotopic salivary gland

Results: A 38-year-old female consulted with a six month history of an enlarging right supraclavicular mass. Fine needle aspiration biopsy was negative for malignant cells. No primary tumor could be demonstrated elsewhere. Excision biopsy was performed and final histopathology revealed pleomorphic adenoma surrounded by a normal lymph node. Atypical tumor cells and mitoses were not found.

Conclusion: Criteria were met for diagnosing heterotopic salivary gland in a supraclavicular lymph node which subsequently developed into pleomorphic adenoma. The rare location of the lesion as well as the unusual histopathological result of pleomorphic adenoma arising from a lymph node merited submission of this case report.

Key words: heteroplasia, heterotopic, cancer, metastasis, tumor

A neck mass is any abnormal enlargement, swelling or growth from the base of the skull to the clavicles. ${ }^{1}$ It is a common clinical finding that presents in patients of all ages. ${ }^{2}$ The differential diagnosis can be extremely broad owing to the various structures located in the neck. Any neck mass in an adult patient must be considered neoplastic and possibly malignant unless proven otherwise. ${ }^{3,4}$ In fact, it is the fear of cancer that usually brings the patient to the physician., ${ }^{5,6}$

An enlarged lymph node is by far the most common neck mass encountered. ${ }^{7}$ It results from a vast array of disease processes ranging from simple lymphadenitis to the more complex neoplastic processes. Hayes Martin emphasized that asymptomatic enlargement of one or more

(C) Philippine Society of Otolaryngology - Head and Neck Surgery, In 


\section{CASE REPORTS}

cervical lymph nodes in the adult is almost always cancer and is due to metastasis from a primary lesion in the mouth or pharynx. ${ }^{8}$

\section{CASE REPORT}

A 38-year-old female from Nueva Ecija was seen for a right supraclavicular mass. Six months prior, the patient noted a mungbean sized mass in the right supraclavicular area, with no associated symptoms such as cough, night sweats or fever. Four months later, the mass had grown to the size of a corn-kernel, still with no other signs or symptoms. A physician treated her for tuberculous adenitis since she had a history of pulmonary tuberculosis two years earlier. The mass continued to grow and after three months, she was referred to our institution for further evaluation and management.

On examination, a $2 \times 2 \mathrm{~cm}$ well-circumscribed, firm, non-tender, right supraclavicular mass was noted. Fine needle aspiration biopsy was negative for malignant cells. Computed tomography scan with contrast revealed a fat-density mass lesion with heterogeneously enhancing structure within the base of the right neck (supraclavicular region). The rest of the vascular, osseous, and soft tissue structures were unremarkable. A hemangiolipoma or inflammatory process was considered.

Referral to, and evaluation by the pulmonology, general surgery, gastroenterology and gynecology services failed to identify a primary, and excision biopsy of the right supraclavicular mass under local anesthesia yielded a homogenous, yellowish-white, firm tumor.

Histopathological findings revealed a well-demarcated typical pleomorphic adenoma showing variously arranged epithelial cells, large amounts of fibrous tissue and numerous small cysts. There was a thin layer of lymphoid tissue at the periphery of the pleomorphic adenoma. (Figure $1 a, b$ ) Serial sections showed the tumor was surrounded completely by lymphoid tissues similar to those of the cortex of lymph node (Figure 1c), suggesting that the pleomorphic adenoma arose in a supraclavicular lymph node and not in major or minor salivary glands which metastasized to the lymph node (Figure 1d). Atypical tumor cells and mitoses were not found.

This case was signed out as benign pleomorphic adenoma occurring as a primary lesion in the supraclavicular lymph node.

\section{DISCUSSION}

Pleomorphic adenoma or benign mixed tumor is the most common tumor of the salivary glands. It occurs commonly in the major salivary glands which include the parotid (70\%), submandibular (10\%) and sublingual (4\%). ${ }^{9}$ Approximately $6.5 \%$ are located in the minor salivary glands distributed in the mucosa of the lips, cheeks, palate, floor of the mouth, tongue, retromolar area and peritonsillar region. Histopathologic diagnosis of pleomorphic adenoma necessitates demonstrating epithelial and myoepithelial cells and a stroma of fibroid, myxoid, chondroid, vascular or myxochondroid characteristics. ${ }^{10}$

Existence of normal salivary gland tissue at sites other than the three major salivary glands and minor salivary glands is described as heterotopia. ${ }^{11}$ Heterotopic salivary gland tissues have been reported in numerous sites throughout the body, including the mandible, ear, palatine tonsil, mylohyoid muscle, pituitary gland, cerebellopontine angle, lower neck and thyroid gland. ${ }^{12}$

It was described for the first time in 1950 by Thompson and Bryant that lymph nodes of varying sizes and shapes are seen within and in close association with parotid gland and parotid tissue. ${ }^{13}$ In 1958, Bernier and Bhaskar first reported the case of a lymph node with pleomorphic adenoma. ${ }^{14}$ According to Baldi et al, pleomorphic adenoma arising in a lymph node is quite rare with less than 20 reported cases in the scientific literature. ${ }^{15}$

Cervical heterotopic salivary tissue may present as a mass, cyst or a draining sinus. ${ }^{16}$ Most of these lesions present early in life, the majority being noticed at birth. The usual clinical presentation is a draining sinus associated with swelling in the right side of the lower neck. Bilateral presentation may also occur. Intermittent drainage is normally reported and has been described as mucoid, clear or saliva-like fluid, sometimes related to meals. ${ }^{17}$

The precise embryogenesis of the heterotopic cervical salivary tissue is still unknown and most theories remain speculative. Different theories are based on their location in the neck. As for heterotopic salivary tissue in the lower neck, Youngs and Scofield suggested a relationship to the branchial apparatus, ${ }^{18}$ with defective closure of the sinus with salivary gland tissue giving rise to heteroplasia of the ectodermal lining within the remnants of the precervical sinus of His. Willis in 1968 proposed three main hypotheses to explain heterotopia. ${ }^{19}$ First, an abnormal persistence and development of vestigial structures; second, dislocation of a portion of a definitive organ rudiment during mass movement and development; and third, abnormal differentiation of the local tissues (heteroplasia).

Theincidentalfinding of pleomorphicadenomain the supraclavicular lymph node would be consistent with the embryonic theory of late invagination of salivary tissue in the parotid region. This leads to the incorporation of salivary tissues within lymph nodes. ${ }^{16}$

Neoplasms arising from heterotopic salivary tissues are uncommon, with about $80 \%$ being benign. ${ }^{16}$ Oncogeneseis of cervical salivary tissue is the presumed origin of these tumors. In a 1999 review of the literature on heterotrophic salivary glands, Ferlito et al found that Warthin's tumor was the most common benign neoplasm with pleomorphic adenoma being the second most commonly reported..$^{19}$ As in our case, the appropriate management for benign neoplasms of cervical heterotopic salivary tissue was local excision with close follow-up. ${ }^{20}$

When pleomorphic adenoma is found in lymph nodes it is important to ascertain whether these are metastases. Chen and Freeman reported that regardless of the primary, metastasizing pleomorphic adenoma maintained benign microscopic appearance except for high mitotic activity and infiltrating growth patterns..$^{21,22}$

The diagnosis of metastasizing pleomorphic adenoma in the lymph node is unlikely in our case, as histopathology revealed pleomorphic adenoma surrounded by a normal lymph node. Further, atypical tumor cells were not found, and there was no sign of mitotic activity or an infiltrating growth pattern, with no primary tumor identified.

According to various authors, the diagnosis of a tumor arising in lymph node is based on the following findings: the tumor was a 
primary lesion with no sign of malignancy, serial section showing that the tumor was confined to the lymphoid tissue and the surrounding lymphoid tissue had the essential characteristics of the lymph node with marginal sinuses and lymph follicles. ${ }^{14,23}$

Fulfilling these criteria, our case is likely that of heterotopic salivary gland in a supraclavicular lymph node which subsequently developed into pleomorphic adenoma. The rare location of the lesion as well as the unusual histopathological result of pleomorphic adenoma arising from a lymph node merited submission of this case report.

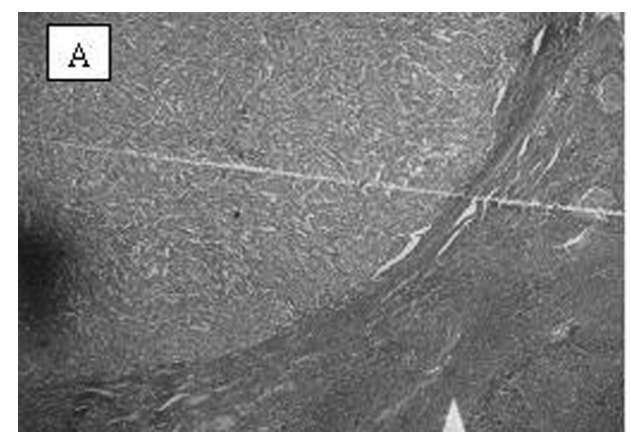

Figure 1-A. Low magnification of pleomorphic adenoma arising in a supraclavicular lymp node. There is a narrow mantle of dense lymphoid tissue around the tumor mass and intranodal heterotopic salivary gland tissue.

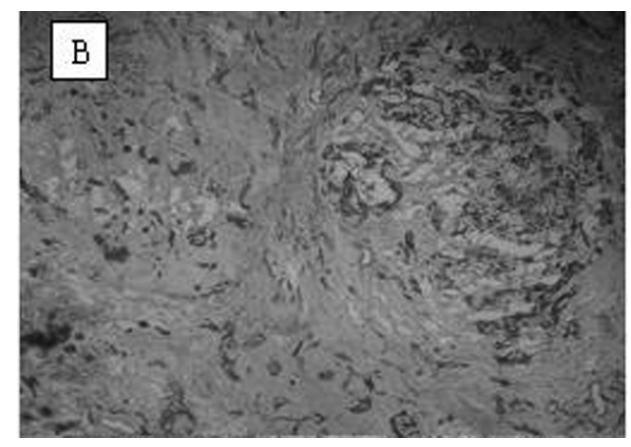

Figure 1-B. The tumor showed various epithelial cells and prominent eosinophilic hyalinized stroma.

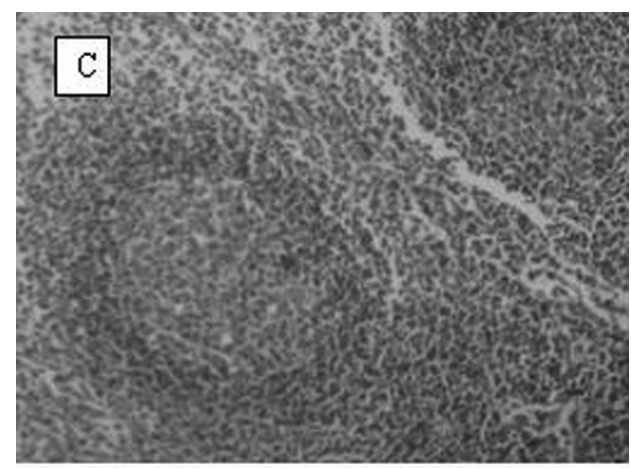

Figure 1-C. High manification of lymphoid tissue. The essential characteristics of the cortex of the lymph node were found.

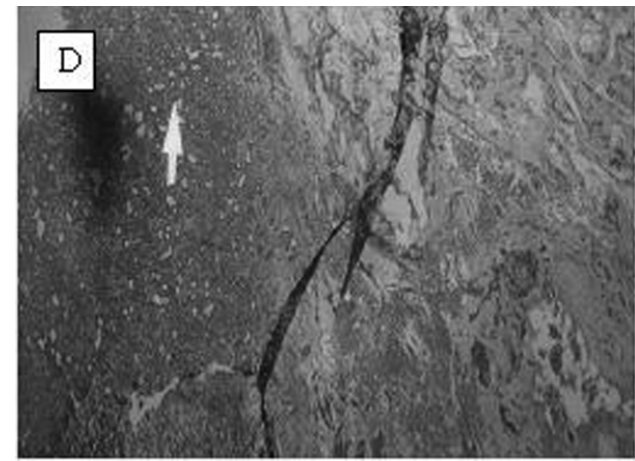

Figure 1-D. Intranodal salivary gland tissue.

\section{REFERENCES}

1. Madigan Army Medical Center [homepage on the internet] United States Army Medical Command (MEDCOM) and Western Regional Medical Command (WRMC) 2007. Referral guidelines by specialty; Ears, Nose, Throat: "Neck mass" [cited 2008 March 10] Available from: http://www.mamc.amedd.army.mil/Referral/guidelines/ent_neckmass

2. Department of Otolaryngology/Head and Neck Surgery, Columbia University Medical Center [homepage on the internet], New York: Columbia University ; c2002-2008 [updated 2008 January 27; cited 2008 March 10]. Head and neck masses. Available from: http://www. entcolumbia.org/hnmass.html.

3. Mc Guirt WF. Differential diagnosis of neck masses. In Cummings CW, Flint P,W Harker L,A Haughey BH, Richardson MA, Robbins KT, Schuller DE, Thomas JR editors. Otolaryngology Head \& Neck Surgery. 4th edition Volume 3, Philadelphia: Elsevier Mosby; 2005. p.2540-53.

4. McGuirt WF: The unknown primary in metastatic head and neck cancer: A clinical approach , NC Med J 1978; 39:299

5. Jakobsen J: Lymph node metastases in the neck from unknown primary tumor, Acta Oncol 1992; 31:653.

6. Nguyen C: Metastatic squamous cell carcinoma to cervical lymph nodes from unknown primary mucosal sites, Head Neck 1994; 16:58

7. ACS Surgery: Principles and Practice, [homepage on the internet].Chicago: American College of Surgeons; c2004. [updated 2008 March 10] Available from: http://beta.acssurgery.com/ acssurgery/institutional/payPerAdd.action?chapterld=part02_ch03.

8. Martin H, Romieu C: The diagnostic significance of a lump in the neck, Postgrad med 1952; 11:491.

9. Eveson JW, Cawson RA. Salivary gland tumors: A review of 240 cases with particular reference to histologic types, sites, age, sex, and sex distribution. J Pathol.1985; 146:51-58.

10. Felix JAP, Tonon S, Saddy J, Meirelles R, Felix F. Pleomorphic adenoma of the nasal septum: A case report and review of literature, Intl Arch Otorhinolaryngol, 2006; 10: 154-8.

11. Rosai J, Major and minor salivary glands. In: Houston M, editor. Surgical Pathology. Vol. 1, New York: Mosby; 2004. p.873-916.

12. Martinez -Madrigal F, Bosq J, Casiraghi O. Major salivary glands. In: Sternberg SS, editor. Histology for Pathologists. Philadelphia: Lipincott-Raven;1997 p.418-419.

13. Thompson AS, Bryant HC. Histogenesis of papillary cystadenoma lymphomatosum (warthin's tumor) of the parotid salivary glands. Am J Pathol 1950; 26: 807-49.

14. Takeda Y, Suzuki A. A Benign Pleomorphic adenoma arising in a parotid lymph node. Virchows Arch[Pathol Anat Histol].1982;396:351-6.

15. Baldi A, Persichetti P, Di Marino MP, Nicoletti G, Baldi F. Pleomorphic adenoma of cervical heterotopic salivary glands. J Exp Clin Cancer Res. 2003;22:645-7.

16. Daniel E, Mc Guirt WF. Neck Masses secondary to heterotopic salivary gland tissue: a 25-year experience. Am J Otolaryngol.2005; 26:96-100.

17. Atienza LL, Rios F, Martin G, Benito A, Bronchalo F, Tello F, Vincent J, et al : Salivary gland heterotopia in lower neck: A report of five cases. Int J Pediatr Otorhinolaryngol. 1998;43:153-61.

18. Youngs LA, Schofiled HH. Heterotopic Salivary gland tissue in the lower neck. Arch Pathol Lab Med 1967; 83: 550-6.

19. Ferlito A, Bertino G, Rinaldo A. A review of heterotopia and associated salivary gland neoplasms of the head and neck. J Laryngol Otol.1999;113:299-303.

20. Rodgers G, Felder H, Yunis EJ. Pleomorphic Adenoma of cervical heterotopic salivary gland tissue: A Case report and review of neoplasms arising in cervical heterotopic salivary gland tissue. Otolaryngol Head and Neck Surg.1991;104:533-6.

21. Freeman SB, Kennedy KS, Parker GS, Tatum SA .Metastasizing Pleomorphic Adenoma of the Nasal Septum, Arch Otolaryngol Head Neck Surg.1990;116:1331-3.

22. Chen KTL, Metastasizing pleomorphic adenoma of the salivary gland. Cancer. 2002; 42: $2407-$ 11.

23. Shinohara M, Ikebe T, Makamura S, Takenoshita Y, Oka M, Mori M,et al. Multiple pleomorphic adenomas arising in the parotid and submandibular lymph nodes. Brit J Oral and Maxillofac Surg 1996;34:515-19. 